\title{
Catalogue of the millipedes (Diplopoda) in Miller's collection (Department of Zoology, National Museum, Prague, Czechia), part 2
}

\author{
Petr Dolejš \& Pavel Kocourek \\ Department of Zoology, National Museum, Cirkusová 1740, CZ-193 00 Praha 9 - Horní Počernice, \\ Czech Republic; e-mail: petr.dolejs@nm.cz, kocourek.pavel@post.cz
}

Dolejš P. \& Kocourek P., 2020: Catalogue of the millipedes (Diplopoda) in Miller's collection (Department of Zoology, National Museum, Prague, Czechia), part 2. - Journal of the National Museum (Prague), Natural History Series 189: 11-20.

\begin{abstract}
The present catalogue completes (as the second of the two parts) data for the millipede collection of Czech arachnologist František Miller (1902-1983), housed in the National Museum in Prague. This second part of the catalogue brings information on a total of 341 specimens belonging to 34 millipede species; these specimens were previously housed at Charles University in Prague, and later moved to the National Museum. The material was collected during 1927-1950 in the territory of modern-day Czechia and Slovakia. Chelogona carpathicum, Polydesmus tatranus and Trachysphaera acutula are species of special importance for Slovak faunistics, due to their endemic occurrence. Glomeris klugii is the first record for Slovakia. For Leptoiulus noricus and Polydesmus inconstans, these are chronologically the oldest records from the territory of Slovakia.
\end{abstract}

Keywords: Diplopoda, myriapodological collection, František Miller, Bohemia, Moravia, Slovakia, faunistics, historical records

Received: May 28, 2020 | Accepted: August 26, 2020 | Published on-line: September 9, 2020

\section{Introduction}

Professor RNDr. František Miller, DrSc. was a significant Czech arachnologist (Kůrka 1994, Buchar 1997, Dolejš \& Tuf 2018, Štáhlavský \& Dolejš 2019), whose large private collection of arachnids and other invertebrates was purchased by the National Museum, Prague, Czechia, from his widow Jarmila Millerová in 1983 and deposited in the Department of Zoology of this museum under accession numbers 100/83 and 103/83 (Kůrka 1994, 1996, 1997, 1998, 2000, 2001, 2003, 2004a, b, Dolejš \& Kůrka 2013, Kocourek \& Dolejš 2016, Dolejš \& Tuf 2018, Štáhlavský \& Dolejš 2019). A catalogue of millipedes from this part of the collection was already published (Kocourek \& Dolejš 2016). However, additional myriapodological material (unsorted and containing many more millipedes) from Miller's collection was transferred to the National Museum from the Faculty of Science, Charles University, Prague, in 2006. 
We therefore present data for this part of collection as a continuation of our previous work (Kocourek \& Dolejš 2016). It contains 341 specimens representing 34 species from all six Central European millipede orders.

The entire millipede collection of the National Museum contains, beside material from former Czechoslovakia (including the south-eastern part of today's Ukraine), also historical material from various countries all over the world. More numerous collections come from the Balkan Peninsula, Borneo, Brazil, Cameroon and Ceylon. Recent material was collected during expeditions of the Department of Entomology of the National Museum to the Dominican Republic, New Zealand, Puerto Rico and South Africa. National Museum hosts also parts of private collections of entomologist Augustin Hoffer (Dolejš \& Kocourek 2018) and myriapodologists Karl W. Verhoeff and Bohumil Němec, including type material (Dolejš \& Kocourek 2019). The collection of František Miller is thus an important part of a series of collections that have belonged to distinguished collectors.

\title{
Material and methods
}

All millipede specimens are kept in $80 \%$ ethanol. All of them were identified by Pavel Kocourek. Nomenclature and arrangement of orders follow Kocourek et al. (2017) and Enghoff \& Kime (2020). Families and species within the orders are sorted alphabetically. The data are arranged as follows: locality (number of mapping grid square), date of collection in a form (often incomplete) as was provided by Miller, number and sex of specimens (inventory number: as a combination of the collection phrase P6E and the specimen number). The division of Czechia into historical areas Bohemia and Moravia for the purposes of the grid square mapping is according to Kment (2009). The numbers of mapping grid squares follow Buchar (1982) and Novák (1989). Photos of selected specimens were made using an Olympus SZX16 stereomicroscope equipped with an Infinity 2 camera and a motor focusing CB-ZM. For SEM examination, selected gonopods were transferred from ethanol into acetone, air-dried, coated with gold and inspected using a scanning electron microscope (HITACHI S-3700N). Abbreviations: $\mathrm{J}=$ juvenile, sad $=$ subadult.

\section{Systematic list}

\section{Order: Polyxenida}

Family: Polyxenidae

\section{Polyxenus lagurus (Linnaeus, 1758)}

CzechiA: Moravia: Pálava (7165-7266), 28 May, 2 q + (P6E 5017).

SLOVAKIA: Čremošné (7179), May 1930, 2 + + (P6E 5018).

\author{
Order: Glomerida \\ Family: Glomeridae
}

Glomeris connexa C. L. Koch, 1847

CzEchiA: Bohemia: Blata near Borkovice (6753), 1 + (P6E 5027); Moravia: Babí lom quarry (6665), 10 April 1948, 1 (P6E 5028); Hády (6766), 18 September 1948, 1 ㅇ (P6E 5029); Mohelno (6863), 1J (P6E 5030).

Glomeris hexasticha Brandt, 1833

Czechia: Bohemia: Blata near Borkovice (6753), March, 1ð 1 ㅇ (P6E 5031); Borkovice (6753), 30 May, 1ð (P6E 5032); Dráchov (6754), 30 April, 1우 1J (P6E 5033); Jindřichův 
Hradec (6855-6856), May 1941, $1 \delta^{1} 19$ (P6E 5034), 7 May 1942, 1ð (P6E 5035); Moravia: Jeseníky Mts. - Skřítek peatbog (6068), June 1949, 1 ㅇ (P6E 5036); Mohelno (6863), 1941, 2 우 2JJ (P6E 5037), 10 April 1943, 1 우 (P6E 5038), 3우우 1J (P6E 5039); Říčky (6764), 24 October 1948, 1 + (P6E 5040).

SLOvAKIA: Gaderská dolina Valley - Mošovce (7079), 1934, 1 q 1J (P6E 5041); Turčianske Teplice (7179), May 1930, 4ðิ $\widehat{\partial} 4$ 우 1J (P6E 5042), 16 June 1931, 2 우 (P6E 5153), "1246A",

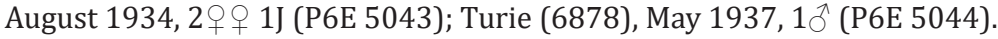

\section{Glomeris klugii Brandt, 1833}

SlovaKia: Turčianske Teplice (7179), April 1930, 1 q (P6E 5045, Figs. 1-2). New species for Slovakia: Turčianske Teplice District, Žilina Region, approx. $48.86^{\circ} \mathrm{N}, 18.86^{\circ} \mathrm{E}$, specific biotope unknown.

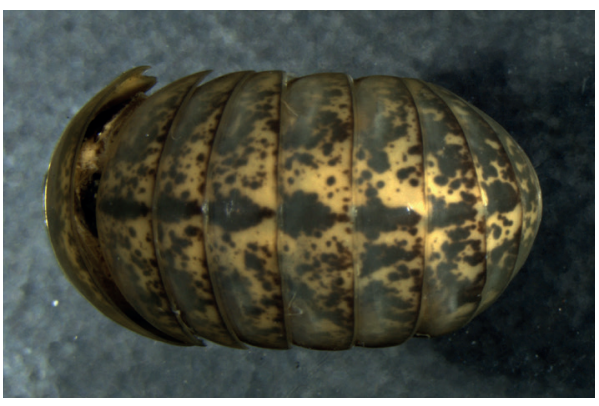

Fig. 1. Glomeris klugii, female from Turčianske Teplice (P6E 5045), dorsal view. New species for Slovakia.

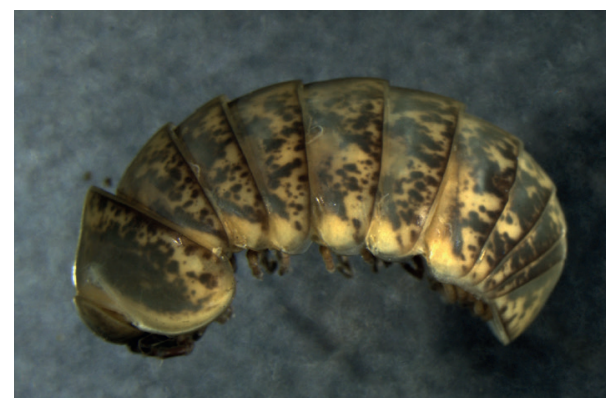

Fig. 2. Glomeris klugii, female from Turčianske Teplice (P6E 5045), lateral view. New species for Slovakia.

\section{Glomeris pustulata Latreille, 1804}

CzEchia: Bohemia: Jindřichův Hradec (6855-6856), 1941, $2 \hat{\jmath} 2$ 우 (P6E 5046); Moravia: Mohelno (6863), 1941, 1 ㅇ (P6E 5047); Pavlovské vrchy Hills (7165-7166), 1 June 1949, 1 ㅇ (P6E 5048).

SlovaKIA: Turčianske Teplice (7179), June 1930, 3 ふ 6 6ㅇ 1J (P6E 5049).

\section{Glomeris tetrasticha Brandt, 1833}

CzEchia: Bohemia: Blata near Borkovice (6753), March, 3 q 9 (P6E 5050).

SlovaKia: Banská Štiavnica (7579), September 1936, 1 đิ 1 + (P6E 5051); Gaderská dolina Valley - Mošovce (7079), 1934, 2 q + (P6E 5052); Turčianske Teplice (7179), May 1931, 1 q (P6E 5053), 16 June 1931, 2 우 (P6E 5154), June 1932, 4 우 (P6E 5054), May 1936, $1 \overbrace{}^{\Uparrow}$ (P6E 5055); Vysoké Tatry Mts. (?), 8-13 September 1944, 3 우 (P6E 5056).

\section{Trachysphaera acutula (Latzel, 1884)}

SlovaKiA: Malá Fatra Mts. (6979), August 1948, 1 (P6E 5057, Fig. 3).

\section{Order: Polyzoniida}

Family: Polyzoniidae

Polyzonium germanicum Brandt, 1837

CzEchiA: Moravia: Jeseníky Mts. (?), 15 June, $1 ð$ (P6E 5019); Jeseníky Mts. - Skřítek peatbog 
(6068), June 1949, 1ð1ㅇ (P6E 5020).

SLOVAKIA: Žilina (6778), 4 우 (P6E 5021).

\section{Order: Julida}

Family: Blaniulidae

\section{Blaniulus guttulatus (Fabricius, 1798)}

SLOVAKIA: Turčianske Teplice "1246A" (7179), August 1934, 1 (P6E 5058).

Choneiulus palmatus (Němec, 1895)

Czechia: Moravia: Mohelno (6863), 10 April 1943, 1 + (P6E 5059).

\section{Nopoiulus kochii (Gervais, 1847)}

SLOVAKIA: Gaderská dolina Valley - Mošovce (7079), 1934, 1 (P6E 5060).

\section{Family: Julidae}

\section{Brachyiulus bagnalli (Curtis, 1845)}

SLovAKIA: Gaderská dolina Valley - Mošovce (7079), 1934, 1 ㅇ (P6E 5061).

\section{Julus curvicornis Verhoeff, 1899}

SLovakiA: Turčianske Teplice "1246A" (7179), August 1934, 1 ㅇ (P6E 5062).

\section{Julus scandinavius Latzel, 1884}

CzechiA: Bohemia: Blata near Borkovice (6753), March, 2JJ (P6E 5063); Borkovice (6753), May 1943, 1ð 2 우 (P6E 5064); Dráchov (6754), 30 April, 2 우 (P6E 5065), 10 May, 3 우 (P6E 5066), May, 1 ㅇ (P6E 5067); Jindřichův Hradec (6855-6856), 17 June 1940, 1 ㅇ (P6E 5068), 1941, 1ð 1ㅇ 2JJ (P6E 5069); Rakovník (5848-5948), 1ㅇ (P6E 5096); Moravia: Babí lom Quarry (6665), 10 April 1948, 1J (P6E 5070); Mohelno (6863), 1941, 1 q 1J (P6E 5071).

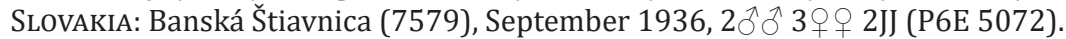

UnKNown (GERMANY?): Rankenheim/Rauhenheim (?), 20 April (1936), 3 우 1J (P6E 5073).

\section{Julus terrestris Linnaeus, 1758}

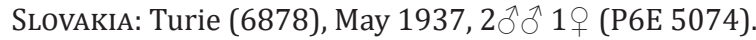

Julus sp.

SLOVAKIA: Čremošné (7179), May 1930, 1J (P6E 5075).

\section{Leptoiulus noricus Verhoeff, 1913}

SlovaKiA: Malá Fatra Mts. (6979), August 1948, 3ðึð 2우 1J (P6E 5076); Turie (6878), August 1948, $2 \AA \widehat{\jmath}$ (P6E 5077).

\section{Leptoiulus proximus (Němec, 1896)}

Czechia: Moravia: Jeseníky Mts. (?), 15 June, $1 \hat{\jmath} 1$ ㅇ (P6E 5078).

\section{Leptoiulus trilobatus (Verhoeff, 1894)}

Czechia: Moravia: Hády (6766), 18 September 1948, 1 (P6E 5079); Jeseníky Mts. (?), June, 2 우 (P6E 5080), July 1949, $1 \delta^{\lambda} 4$ 우 (P6E 5081); Říčky (6764), 24 October 1948, 1 우 (P6E 5082).

SLOVAKIA: Turčianske Teplice (7179), 20 May 1932, 1ð 1 ㅇ (P6E 5083). 


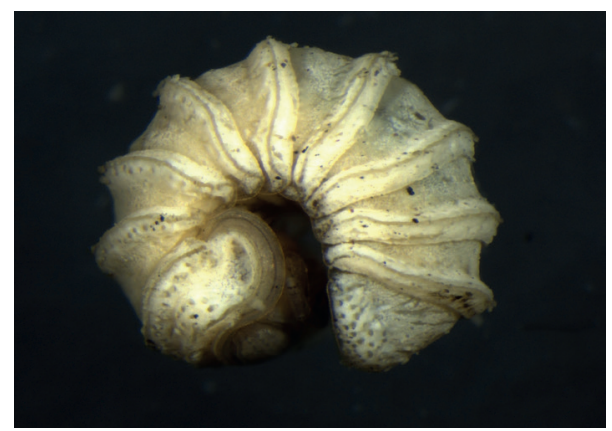

Fig. 3. Trachysphaera acutula, female from Malá Fatra Mts. (P6E 5057), lateral view.

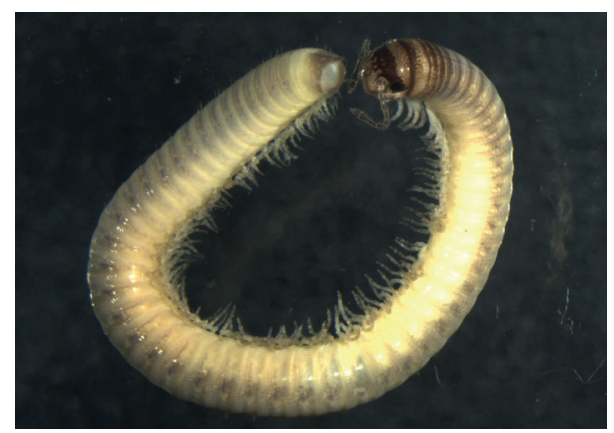

Fig. 4. Leptoiulus tussilaginis, female from Malá Fatra Mts. (P6E 5084), habitus.

\section{Leptoiulus tussilaginis (Verhoeff, 1907)}

SlOVAKIA: Malá Fatra Mts. (6979), August 1948, 1 đ̊ 2 + (P6E 5084, Figs. 4-5).

\section{Leptoiulus sp.}

SlovaKIA: Vysoké Tatry Mts. (?), 8-13 September 1944, 4우 ㅇ (P6E 5085).

\section{Megaphyllum projectum Verhoeff, 1894}

Czechia: Bohemia: Dráchov (6754), 10 May, 1J (P6E 5086); Třeboň (6954), May 1928, 1 q (P6E 5087); Moravia: Hády (6766), 18 September 1948, 1 ㅇ (P6E 5088); Jeseníky Mts. (?), June, 1J (P6E 5089).

Slovakia: Banská Štiavnica (7579), September 1936, 3 우 (P6E 5090); Čremošné (7179), May 1930,1ㅇ 1J (P6E 5091); Domica (7588), August 1948, 1J (P6E 5092); Turčianske Teplice (7179), 20 May 1932, 1ð1 1 (P6E 5093).

\section{Megaphyllum unilineatum (C. L. Koch, 1838)}

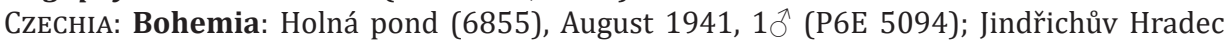
(6855-6856), 1941, 2 우 (P6E 5095); Moravia: Mohelno (6863), 1941, 6우 우 1J (P6E 5097), 10 April 1943, 1 q 1J (P6E 5098); Pavlovské vrchy Hills (7165-7166), 1 June 1949, 1 q (P6E 5099).

SlovAKIA: Banská Štiavnica (7579), September 1936, 1 đ̊ 19 (P6E 5100); Čremošné (7179), May 1930, 1 ㅇ (P6E 5101); Domica (7588), August 1948, 4 우 우 3JJ (P6E 5102); Gaderská dolina Valley - Mošovce (7079), 1934, 1+ 2JJ (P6E 5103); Turčianske Teplice "1246A" (7179), August 1934, $2 \widehat{\delta} 3$ 우우 2JJ (P6E 5104); Turie (6878), May 1937, 1 우 (P6E 5105).

\section{Ommatoiulus sabulosus (Linnaeus, 1758)}

CzECHIA: Moravia: Mohleno (6863), 1941, 2 우 (P6E 5106).

SLOVAKIA: Banská Štiavnica (7579), September 1936, 1 + (P6E 5107); Gaderská dolina Valley - Mošovce (7079), 1934, 2 đ̂̃ 2 우 (P6E 5114); Malá Fatra Mts. (6979), August 1948, 2 우 (P6E 5108).

\section{Rossiulus vilnensis (Jawlowski, 1925)}

CzechiA: Bohemia: Blata near Borkovice (6753), March, 1 ㅇ (P6E 5109); Borkovice (6753),

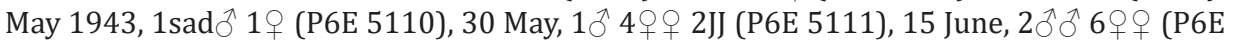
5112); Dráchov (6754), May, 2 우, 1J (P6E 5113).

Unciger foetidus (C. L. Koch, 1838)

Czechia: Bohemia: Jindřichův Hradec (6855-6856), June 1940, 1ð (P6E 5115); Moravia: 
Babí lom quarry (6665), 10 April 1948, 1 (P6E 5116); Hády (6766), 18 September 1948,

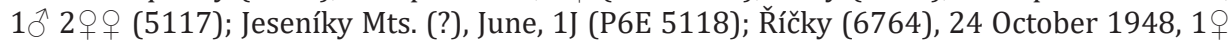
(5119).

SLOVAKIA: Banská Štiavnica (7579), September 1936, 1 q (P6E 5120); Gaderská dolina Valley - Mošovce (7079), 1934, 1 đ 4 우 1J (P6E 5121); Malá Fatra Mts. (6979), August 1948, 1 ㅇ (P6E 5122); Turčianske Teplice (7179), 20 May 1932, 1 + (P6E 5123), "1246A", August 1934

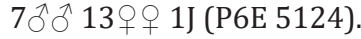

Order: Chordeumatida

Family: Chordeumatidae

Mycogona germanica (Verhoeff, 1892)

Czechia: Moravia: Jeseníky Mts. (?), 15 June, 1 (P6E 5022).

Family: Craspedosomatidae

Chelogona carpathicum (Latzel, 1882)

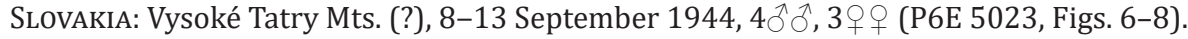

Craspedosoma transsylvanicum Verhoeff, 1897

Czechia: Moravia: Pouzdřany (7065), 1 April 1950, 1ð̂ (P6E 5024).

Family: Haaseidae

Haasea flavescens (Latzel, 1884)

Czechia: Bohemia: Rakovník (5848-5948), 17 June 1927, 1 ㅇ (P6E 5025).

Family: Mastigophorophyllidae

Mastigona bosniensis (Verhoeff, 1897)

SLovAKIA: Banská Štiavnica (7579), September 1936, 2 + 9 (P6E 5026).

Order: Polydesmida

Family: Polydesmidae

\section{Polydesmus complanatus (Linnaeus, 1761)}

CzECHIA: Bohemia: Jindřichův Hradec (6855-6856), 1941, 1ð 1ㅇ 2JJ (P6E 5125); Moravia:

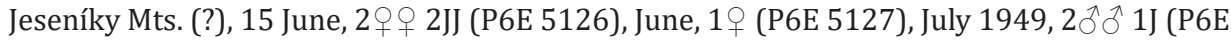
5128); Mohelno (6863), 1941, 4 JJ (P6E 5129), 10 April 1943, 1 ㅇ (P6E 5130)

SLOVAKIA: Banská Štiavnica (7579), September 1936, 1 đ 2 우 2JJ (P6E 5131); Čremošné (7179), May 1930, 1ð 2JJ (P6E 5132); Gaderská dolina Valley - Mošovce (7079), 1934, $1 \delta$ 2 웅 (P6E 5133); Malá Fatra Mts. (6979), August 1948, 1 ㅇ (P6E 5134); Modré pleso Lake, 2200 m a.s.l. (6887), 12 April 1948, 1 ㅇ (P6E 5135); Turčianske Teplice (7179), 16 June 1931,

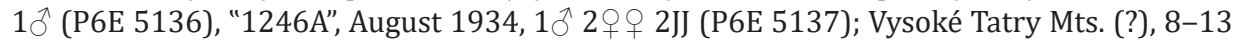

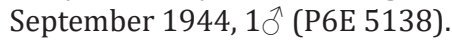

UNKNOWn (GERMANY?): Rankenheim/Rauhenheim (?), 20 April (1936), 1ð 1J (P6E 5139). 


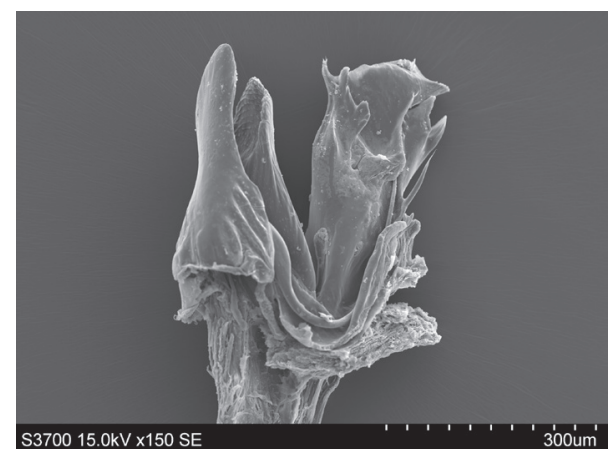

Fig. 5. Leptoiulus tussilaginis, male from Malá Fatra Mts. (P6E 5084), left gonopod, internal (medial) view (SEM).

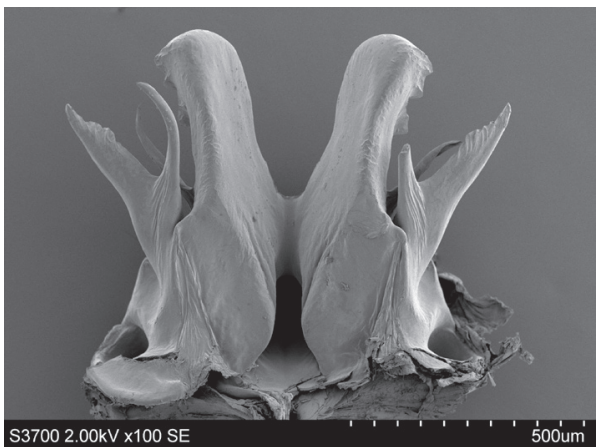

Fig. 7. Chelogona carpathicum, male from Vysoké Tatry Mts. (P6E 5023), anterior gonopods, anterior view (SEM).

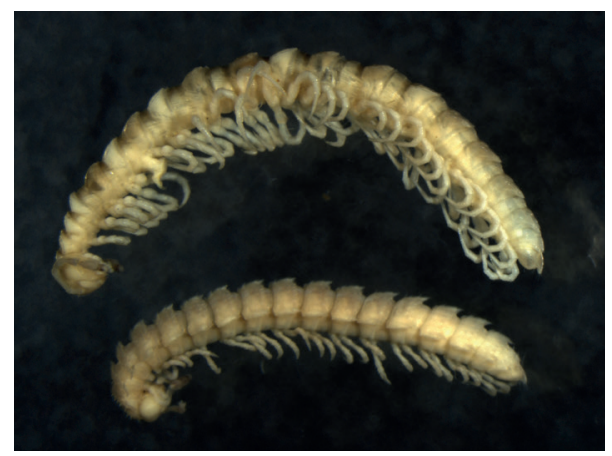

Fig. 9. Polydesmus tatranus, male and female from Turie by Žilina (P6E 5154), habitus, lateral view.

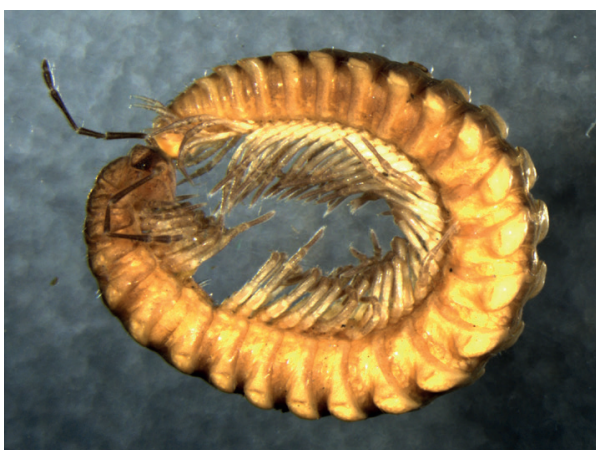

Fig. 6. Chelogona carpathicum, male from Vysoké Tatry Mts. (P6E 5023), habitus.

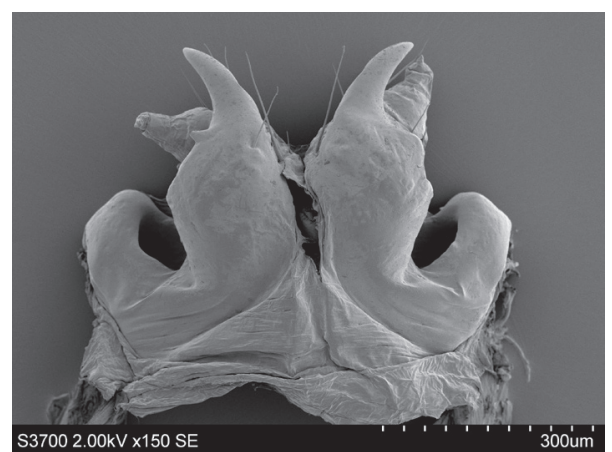

Fig. 8. Chelogona carpathicum, male from Vysoké Tatry Mts. (P6E 5023), posterior gonopods, anterior view (SEM).

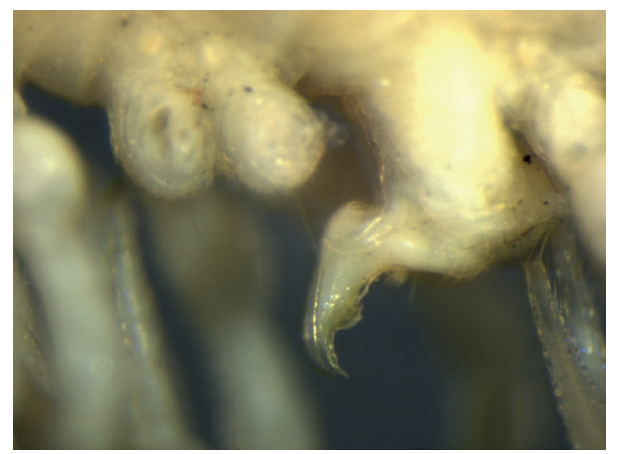

Fig. 10. Polydesmus tatranus, male from Turie by Žilina (P6E 5154), gonopods. 
Polydesmus denticulatus C. L. Koch, 1847

CzechiA: Bohemia: Borkovice (6753), 30 May, 1ð1ㅇ (P6E 5140).

SLOVAKIA: Turčianske Teplice (7179), 16 June 1931, 1 đ (P6E 5141).

Polydesmus inconstans Latzel, 1884

SlovaKIA: Turčianske Teplice "1246A" (7179), August 1934, 1ð 2 ㅇ 1 1J (P6E 5142).

\section{Polydesmus tatranus Latzel, 1884}

Slovakia: Turie (6878), August 1948, $1 \hat{\jmath} 1$ 1 (P6E 5152, Figs. 9-10).

\section{Polydesmus sp.}

CzechiA: Bohemia: Dráchov (6754), May, 1J (P6E 5143); Holná pond (6855), August 1941, 1J (P6E 5144); Moravia: Lednice (7266), 15 May 1950, 1J (P6E 5145).

SLOVAKIA: Turie (6878), May 1937, 2JJ (P6E 5146).

\section{Strongylosoma stigmatosum (Eichwald, 1830)}

CzechiA: Bohemia: Třeboň (6954), May 1928, 2 우 (P6E 5147); Moravia: Bobrava valley (6865) 5 April, 3 우 (P6E 5148); Jeseníky Mts. (?), July 1949, 1 ㅇ (P6E 5149).

SLovaKIA: Gaderská dolina Valley - Mošovce (7079), 1934, 1 đ1 1 + (P6E 5150); Turie (6878), May 1937, 1 (P6E 5151).

\section{Discussion}

Voucher material of many historical records of millipedes from Czechia has been lost, including that related to the monograph of Lang (1954). Therefore, the historical millipede collection deposited in the National Museum in Prague is very valuable. It documents the millipede fauna for more than 70 years ago (Kocourek 2001).

František Miller was interested mainly in the linyphiid spiders (Buchar 1997, Dolejš \& Kůrka

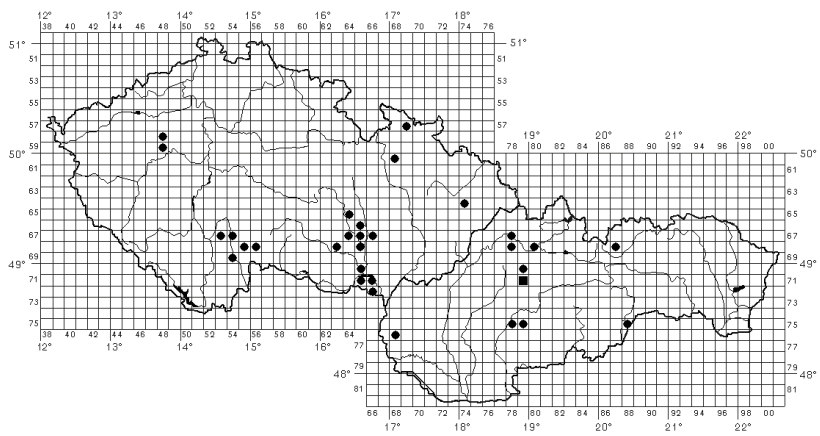

Fig. 11. Map of localities where Miller collected the millipedes in Czechia (left) and Slovakia (right) except for inaccurate localization for Jeseníky Mts. and Vysoké Tatry Mts. The map is based on data both from Kocourek \& Dolejš (2016) and this work. Square = distributional mark for Glomeris klugii.

2013), so the fates of other invertebrates collected by him varied widely. Publications through the present from the non-spider groups include: some of Miller's records of woodlice from Žilina (Frankenberger 1959), catalogues of woodlice (Dolejš \& Tuf 2018), false scorpions (Štáhlavský \& Dolejš 2019) and those millipedes that were found in Miller's mixed samples in the National Museum (Kocourek \& Dolejš 2016). This contribution lists those millipedes from Miller's collection that were transferred to the Museum from Charles University relatively recently.

Altogether, based on data from Kocourek \& Dolejš (2016) and this contribution, Miller's millipede collection contains 454 (plus 24 dataless) specimens representing 44 species belonging to six orders. They were collected in modern-day Czechia, Slovakia (Fig. 11), Croatia (see Dolejš \& Tuf 2018), Bosnia and Herzegovina, and at an unclear locality "Rankenheim" 
or "Rauhenheim" (that could be in Germany) between 1927 and 1969. Miller's locality labels are rather simple; beside (often incomplete) date, they include only a name of a town or locality, without further details on biotope. Despite part of Miller's diary being available, notes about specific collecting sites are missing, so we were able to assign at the most the mapping grid square.

Beside species occurring in Czechia and Slovakia, the collection also contains Glomeris pulchra C. L. Koch, 1847 and Polydesmus collaris C. L. Koch, 1847, collected at the Balkan Peninsula (Kocourek \& Dolejš 2016). From the faunistic point of view, the collection provides historical records of particular value primarily for Slovakia: Chelogona carpathicum, Polydesmus tatranus and Trachysphaera acutula are species of special importance, as they are endemic to the Carpathians and relatively rare (e.g. Kime \& Enghoff 2011). In addition, the record of $P$. tatranus seems to be one of its westernmost occurrences (cf. Kime \& Enghoff 2011). Leptoiulus noricus and Polydesmus inconstans are documented chronologically as the oldest records from the territory of Slovakia (cf. Mock 2004). Glomeris klugii is the first record for Slovakia (cf. Mock 2001; Enghoff \& Kime 2020). Despite the record of Glomeris klugii being based only on one female, it broadens the known distribution of the species much to the East, to the probable easternmost border of its areal (cf. Kime \& Enghoff 2011). Because the specimen is well dated and localized, it is certainly appropriate to note verification of the given easternmost point of its occurrence currently known.

\section{Acknowledgements}

We thank Janet Beccaloni (London) for sorting part of the millipedes out of the mixed myriapodological samples. We also thank the reviewers (Andrej Mock and Karel Tajovský) for their valuable comments and corrections. This work was financially supported by the Ministry of Culture of the Czech Republic (DKRVO 2019-2023/6.I.a-b, National Museum, 00023272).

\section{References}

Buchar J., 1982: Způsob publikace lokalit živočichů z území Československa. Publication of faunistic data from Czechoslovakia. - Věstník Československé Společnosti Zoologické 46: 317-318. [In Czech.]

Buchar J., 1997: In memory of the late Professor Miller on his 95th birthday. - Acta Societatis Zoologicae Bohemicae 61: 275-278.

Dolejš P., Kocourek P., 2018: Catalogue of the millipedes (Diplopoda) in the Hoffer's collection at the National Museum in Prague, Czech Republic. - Schubartiana 7: 1-6.

Dolejš P., Kocourek P., 2019: Bohumil Němec and his millipede collection at the National Museum in Prague (Czechia), with notes on Craspedosoma rawlinsii simplex Němec, 1896. - Schubartiana 8: 25-35.

Dolejš P., Kůrka A., 2013: Catalogue of spiders (Araneae) in Miller's collection (Department of Zoology, National Museum). Part X: Linyphiidae, genera A-M, from Czechia and Slovakia. - Journal of the National Museum (Prague), Natural History Series 182: 1-27.

Dolejš P., Tuf I.H., 2018: Catalogue of the woodlice (Isopoda: Oniscidea) in Miller's collection in the Department of Zoology, National Museum, Prague. - Acta Societatis Zoologicae Bohemicae 82: 9-16.

Enghoff H., Kime D.R., 2020: Diplopoda. Fauna Europaea version 2020.05. - http://www. fauna-eu.org [Accessed on 27 May 2020.]

Frankenberger Z., 1959: Stejnonožci suchozemští - Oniscoidea [Woodlice - Oniscoidea]. Fauna ČSR. Vol. 14: 212 pp. Praha: Nakl. ČSAV. [In Czech.]

Kime R.D., Enghoff H., 2011: Atlas of European Millipedes (Class Diplopoda). Volume 1. Orders Polyxenida, Glomerida, Platydesmida, Siphonocryptida, Polyzoniida, Callipodida, Polydesmida. - Fauna Europaea Evertebrata 3. Sofia, Moscow: Pensoft, 282 pp. 
Kment P., 2009: Čechy a Morava pro potřeby faunistického výzkumu. Bohemia and Moravia for the purposes of faunistic research. - Klapalekiana 45: 287-291. [In Czech.]

Kocourek P., 2001: Druhová rozmanitost českých mnohonožek v historickém kontextu [Species diversity of the Czech millipedes in the historical context]. - In: Tajovský K. (ed.): Myriapodologica Czecho-Slovaca 1: 59-60. České Budějovice: Institute of Soil Biology, Academy of Science of the Czech Republic. [In Czech.]

Kocourek P., Dolejš P., 2016: Catalogue of millipedes (Diplopoda) in Miller's collection (Department of Zoology, National Museum, Prague, Czechia). - Journal of the National Museum (Prague), Natural History Series 185: 25-31.

Kocourek P., Tajovský K., Dolejš P., 2017: Mnohonožky České republiky - Př́ručka pro určování našich druhů [Millipedes of the Czech Republic - Guide for identification of our species]. - Vlašim: Český svaz ochránců př́rody Vlašim: 256 pp. [In Czech.]

Kůrka A., 1994: Přehled druhů pavouků (Araneida) ve sbírce Prof. F. Millera (zoologické sbírky Př́rodovědeckého muzea - Národního muzea), část I [A survey of spiders (Araneida) in Prof. F. Miller's collection (Department of Zoology, Museum of Natural History - National Museum), part I]. - Časopis Národního Muzea, Řada př́rodovědná 163: 43-54. [In Czech.]

Kůrka A., 1996: A survey of spider species (Araneida) in Prof. F. Miller's collection (Department of Zoology, Museum of Natural History, National Museum), part II. - Časopis Národního Muzea, Řada přírodovědná 165: 133-138.

Kůrka A., 1997: A survey of spider species (Araneida) in Prof. F. Miller's collection (Department of Zoology, Museum of Natural History - National Museum), part III: Thomisidae and Philodromidae. - Časopis Národního Muzea, Ǩada přírodovědná 166: 47-53.

Kůrka A., 1998: A survey of spider species (Araneida) in Prof. F. Miller's collection (Department of Zoology, Museum of Natural History - National Museum), part IV: Lycosidae. - Časopis Národního Muzea, Řada př́rodovědná 167: 35-42.

Kůrka A., 2000: A survey of spider species (Araneae) in Prof. F. Miller's collection (Department of Zoology, Museum of Natural History - National Museum), part V. - Časopis Národního Muzea, Řada př́rodovědná 169: 35-40.

Kůrka A., 2001: A survey of spider species (Araneae) in Prof. F. Miller's collection (Department of Zoology, Museum of Natural History - National Museum), part VI: Salticidae. - Časopis Národního Muzea, Řada př́rodovědná 170: 81-89.

Kůrka A., 2003: A survey of spider species (Araneida) in Prof. F. Miller's collection (Department of Zoology, Museum of Natural History - National Museum), part VII: Theridiidae. Časopis Národního Muzea, Řada př́rodovědná 172: 133-140.

Kůrka A., 2004a: A survey of spider species (Araneida) in Prof. F. Miller's collection (Department of Zoology, Museum of Natural History - National Museum), part VIII: Araneidae. - Časopis Národního Muzea, Řada přírodovědná 173: 29-34.

Kůrka A., 2004b: A survey of spider species (Araneida) in Prof. F. Miller's collection (Department of Zoology, Museum of Natural History - National Museum), part IX: Nesticidae, Tetragnathidae and Dictynidae (part). - Časopis Národního Muzea, Řada př́rodovědná 173: 35-38.

Lang J., 1954: Mnohonožky - Diplopoda. - Fauna ČSSR, svazek 2. Praha: ČSAV, 188 pp. [In Czech.] Mock A., 2001: Millipedes (Diplopoda) of the Slovak Republic. - Myriapodologica CzechoSlovaca 1: 25-38.

Mock A., 2004: First record of Polydesmus inconstans Latzel, 1884 (Diplopoda, Polydesmidae) in Slovakia. - Biologia, Bratislava 59: 552.

Novák I., 1989: Seznam lokalit a jejich kódů pro sítové mapování entomofauny Československa [List of localities and their codes for grid mapping of Czechoslovak entomofauna]. Zprávy Československé společnosti entomologické při ČSAV 25: 3-84. [In Czech.]

Štáhlavský F., Dolejš P., 2019: Catalogue of the pseudoscorpions (Pseudoscorpiones) in František Miller's collection (Department of Zoology, National Museum, Prague). Arachnologische Mitteilungen 58: 18-22. https://doi.org/10.30963/aramit5807 